\title{
Cost-benefit of three different methods for studying Mediterranean rocky benthic assemblages
}

\author{
Natàlia Sant ${ }^{1}$, Eglantine Chappuis ${ }^{1}$, Conxi Rodríguez-Prieto ${ }^{2}$, Montserrat Real ${ }^{3}$, \\ Enric Ballesteros ${ }^{1}$

\begin{abstract}
${ }^{1}$ Centre d'Estudis Avançats de Blanes, Consell Superior d'Investigacions Científiques (CEAB-CSIC), C/accés a la Cala (EC) E-mail: eglantinemaria@hotmail.com. ORCID iD: http://orcid.org/0000-0003-1601-6683

(EB) (Corresponding author) E-mail: kike@ceab.csic.es. ORCID iD: http://orcid.org/0000-0001-5532-5337

${ }^{2}$ Departament de Ciències Ambientals, Facultat de Ciències, Universitat de Girona (UdG), Campus de Montilivi, 17071 Girona, Spain. E-mail: conxi.rodriguez@udg.edu. ORCID iD: http://orcid.org/ 0000-0003-4935-1250 ${ }^{3}$ AECOM URS España SLU, C/ Urgell 143, 4-1, 08036 Barcelona, Spain.

(MR) E-mail: montserrat.real@aecom.com. ORCID iD: http://orcid.org/0000-0001-7357-6789
\end{abstract} \\ St. Francesc 14, 17300 Blanes, Spain. (NS) E-mail: natsfunk@ gmail.com. ORCID iD: http://orcid.org/0000-0002-5660-0131
}

\begin{abstract}
Summary: Here we compare the applicability, the information provided and the cost-benefit of three sampling methods usually used in the study of rocky benthic assemblages. For comparative purposes, sampling was performed seasonally and along a depth gradient $(0-50 \mathrm{~m})$ in the Cabrera Archipelago (western Mediterranean). The destructive scraping (collection) method was the least cost-effective but provided the best qualitative and quantitative information. The in situ visual method was the most time-effective but provided low levels of taxonomic resolution and its accuracy decreased with depth due to the increasing difficulty of recognizing species in situ due to nitrogen narcosis, reduced light and cold. The photoquadrat method showed intermediate values of cost-effectiveness and information but was not suitable for multilayered assemblages, as it only accounted for the overstory. A canonical correspondence analysis showed that depth was highlighted as the main environmental gradient (16.0\% of variance) by the three methods. However, differences due to the sampling method ( $7.9 \%$ of variance) were greater than differences due to temporal variability (5.8\% of variance), suggesting that the three methods are valid but their selection has to be carefully assessed in relation to the targeted assemblages and the specific goals of each study.
\end{abstract}

Keywords: rocky benthic assemblages; destructive and non-destructive sampling methods; photoquadrats; depth gradient; seasonality.

Costes y beneficios de tres métodos de estudio de comunidades en el bentos rocoso mediterráneo

Resumen: Este trabajo compara la aplicabilidad, la calidad de la información, los costes y los beneficios de tres métodos de muestreo usados habitualmente en el estudio de comunidades en el bentos rocoso mediterráneo. Para fines comparativos, el muestreo se realizó estacionalmente y a lo largo de un gradiente de profundidad $(0-50 \mathrm{~m})$ en el Archipiélago de Cabrera (Mediterráneo Occidental). El método destructivo de raspado (recolección) tuvo altos costes, pero proporcionó la información de mejor calidad, tanto a nivel cualitativo como cuantitativo. El método visual in situ fue el más eficiente en cuanto a la obtención de información, pero proporcionó una baja resolución taxonómica y su exactitud decreció con la profundidad debido a la dificultad de reconocer especies in situ bajo condiciones de narcosis, falta de luz y frío. El método fotográfico obtuvo valores intermedios de coste-beneficio, pero no fue adecuado para caracterizar comunidades estratificadas ya que solo tuvo en cuenta el estrato superior. Un análisis CCA mostró que el principal gradiente ambiental resaltado en todos los métodos era la profundidad (16.0\% de la varianza). Sin embargo, las diferencias debidas al método de muestreo (7.9\% de la varianza) fueron más grandes que las debidas a la variabilidad estacional (5.8\% de la varianza). En consecuencia, los tres métodos son válidos para el muestreo de comunidades rocosas mediterráneas, pero su selección debe basarse en un análisis minucioso de las comunidades a caracterizar y en los objetivos específicos de cada estudio.

Palabras clave: comunidades del bentos rocoso; métodos de muestreo destructivos y no destructivos; cuadrados fotográficos; gradiente de profundidad; estacionalidad.

Citation/Como citar este artículo: Sant N., Chappuis E., Rodríguez-Prieto C., Real M., Ballesteros E. 2017. Cost-benefit of three different methods for studying Mediterranean rocky benthic assemblages. Sci. Mar. 81(1): 129-138. doi: http://dx.doi. org/10.3989/scimar.04463.04A

\section{Editor: J.S. Troncoso}

Received: April 25, 2016. Accepted: November 21, 2016. Published: January 10, 2017.

Copyright: (C) 2017 CSIC. This is an open-access article distributed under the terms of the Creative Commons Attribution (CC-by) Spain 3.0 License. 


\section{INTRODUCTION}

The study of community organization patterns is essential in ecology as it provides a descriptive basis to further develop hypothesis, build models, design experiments or perform monitoring fieldwork. Using the appropriate methodology is fundamental to obtain an accurate description of the assemblages as well as qualitative and quantitatively representative samples (Bellan-Santini 1963, Boudouresque 1971, Martin et al. 1993). The optimum and feasible sampling method is ultimately determined by the type of information needed, together with the material and time resources available. The selected methodology has to optimize the balance between obtained information and working effort.

SCUBA diving allows marine scientists to study benthic assemblages in situ by means of a wide variety of sampling methods. Dredging and other similar remote techniques used on soft bottoms are not appropriate for rocky bottoms as they provide incomplete information of the system (Russell 1990). Therefore, rocky bottoms at relatively shallow depths are often studied by SCUBA diving, which can provide qualitative and quantitative data for statistically elucidating distribution and abundance patterns of species (Littler and Littler 1985). There are two main types of technique: a) destructive techniques that imply the partial removal of the assemblages and b) non-destructive techniques that leave the assemblage undamaged.

The classic destructive method consists in scraping and collecting all existing organisms of a known area (Bellan-Santini 1963, True 1964, Boudouresque 1971). The organisms are later identified and quantified in the laboratory. Numerous descriptive studies have used this methodology in the Mediterranean Sea (Romero 1981, Airoldi et al. 1995, Ballesteros et al. 1998 among others), Western Europe (Niell 1979), Africa (John et al. 1977, McQuaid 1985), North America (Mann 1972, Calvin and Ellis 1978) and Asia (Sakai 1977).

Non-destructive direct methods use quadrats of a specific area to estimate the species cover percentage or frequency. Data are estimated in situ using sub-quadrats (area, Dethier et al. 1993, Parravicini et al. 2010, Bertocci et al. 2012) or point-quadrats (contact points, Foster et al. 1991, Dethier et al. 1993, Benedetti-Cecchi et al. 1996). Data are obtained almost immediately but the results depend on the previous taxonomical knowledge of the diver. These methods are less precise than the scraping technique but are faster, allowing larger areas to be sample and more replicates to be collected. They have often been used in long-term monitoring as the assemblages are undamaged (Dayton 1971, Gunnill 1980, Sebens 1986).

Non-destructive indirect methods use photos or video to estimate species cover percentage or frequency. Diving time is short but the subsequent frame treatment is long. Cover data is finally estimated using sub-quadrats (Bussotti et al. 2006, Deter et al. 2012), contact points (Foster et al. 1991, Meese and Tomich 1992, Van Rein et al. 2011) or species patches (Garrabou et al. 2002, Piazzi et al. 2014). These methods have increased in popularity and specific image processing software for them has been released (e.g. Trygonis and Sini 2012). They have been used to study the growth and population dynamics of modular organisms (Hughes and Jackson 1985, Garrabou 1999), to study the spatial heterogeneity of benthic assemblages (Garrabou et al. 1998, Teixido et al. 2002, Kipson et al. 2011), and in long-term monitoring activities (Bussotti et al. 2006, Teixido et al. 2011).

The different methods for studying rocky benthic assemblages also provide contrasting information and different cost-benefits. It is essential to assess the quality of the information obtained and the effort and cost of the sampling methodology used because sampling is the first information filter. The comparison of different methods helps researchers to select the best one for attaining their goals. Several methods for studying rocky benthic assemblages have been compared in different locations (e.g. Dethier et al. 1993, Mantelatto et al. 2013, Schonberg 2015), but studies are lacking in the Mediterranean area (but see Benedetti-Cecchi et al. 1996, Parravicini et al. 2010, Piazzi et al. 2014). More direct and quantitative comparisons between different methodologies are needed, especially comparing destructive vs. non-destructive methods. Here, we aim to compare the applicability of three common sampling methods. We selected a destructive method (the collection method), a non-destructive direct method (the in situ visual method) and a non-destructive indirect method (the photoquadrat method). The information quality and cost-benefit of each method was evaluated by studying five communities situated along a depth gradient (from 0 to $50 \mathrm{~m}$ ) and in four different seasons in Cabrera Archipelago rocky bottoms (western Mediterranean).

\section{MATERIALS AND METHODS}

\section{Study site}

The study site was located at "Estell des Coll" $\left(39^{\circ} 07^{\prime} 19^{\prime \prime} \mathrm{N}, 2^{\circ} 56^{\prime} 09^{\prime \prime} \mathrm{E}\right)$, a small islet within the Archipelago of Cabrera National Park (Balearic Islands, western Mediterranean). Five benthic assemblages were studied along a vertical transect at 0 (A0), 4 (A4), 12 (A12), 25 (A25) and 50 (A50) metres depth along a rocky cliff in four different seasons: winter, spring, summer and autumn.

Assemblage A0 was strongly multilayered with a dense canopy of the brown alga Cystoseira stricta and some epiphytes (e.g. Haliptilon virgatum, Jania rubens and Ceramium spp.). The midstory included Palisada tenerrima, Laurencia sp., Anadyomene stellata and Valonia utricularis among others, and the understory mainly consisted of the crustose alga Neogoniolithon brassica-florida. Abundant invertebrates were ascidians (Trididemnum cereum and Didemnum granulosum), some hydrozoans (Aglaophenia kirchenpaueri), small crustaceans and bryozoans (Crisia spp.)

Assemblage A4 was a photophilic algal assemblage covered by small erect algae, such as Dictyota fasciola and Padina pavonica. The understory was dominated 
by Neogoniolithon brassica-florida and Lobophora variegata. The sponges Crambe crambe, Sarcotragus spinosulus and Sarcotragus fasciculatus were also abundant.

Assemblage A12 was dominated by the canopyforming alga Cystoseira balearica together with erect algae such as Dictyopteris polypodioides, Sargassum vulgare, Halopteris scoparia, Dictyota dichotoma and Peyssonnelia spp. The understory consisted of crustose Neogoniolithon brassica-florida, Polystrata fosliei and Lobophora variegata. The most abundant invertebrates were the sponges Crambe crambe, Phorbas topsenti, Sarcotragus spinosulus and S. fasciculatus, the tunicate Diplosoma spongiforme and the cnidarian Clavularia crassa.

The brown erect alga Dictyopteris polypodioides dominated assemblage A25. The midstory consisted of the erect algae Peyssonnelia spp., Halopteris filicina, Leptofauchea coralligena and Flabellia petiolata, among others. The understory consisted mainly of the crustose algae Mesophyllum alternans, Neogoniolithon mamillosum and Peyssonnelia rosa-marina. Invertebrates such as bryozoans (Myriapora truncata, Cellepora pumicosa), sponges (Phorbas topsenti, Crambe crambe), tunicates (Pseudodistoma cyrnusense), cnidarians (Alcyonium coralloides, Clavularia crassa) and polychaetes were also common.

A coralligenous assemblage was present at the bottom of the cliff (A50), dominated by the crustose calcareous alga Mesophyllum alternans, with Lithophyllum incrustans, Neogoniolithon mamillosum and Peyssonnelia rosa-marina, among others. Erect algae (e.g. Flabellia petiolata, Halopteris filicina) were also present. Abundant invertebrates were cnidarians (Leptopsammia pruvotii), sponges (Axinella damicornis), bryozoans (Myriapora truncata, Rynchozoon neapolitanum), polychaetes and small crustaceans.

\section{Sampling methods}

Sample collection was performed by SCUBA diving, except for A0. Sampling time, especially at $50 \mathrm{~m}$, was the main limiting factor. The five assemblages were sampled in each season with three different sampling methods: the collection (scraping) method, the in situ visual method and photoquadrats. Two dives by three divers were needed to obtain the samples in each season. The in situ relevés (visual method) were always made by the same experienced diver. The other two divers collected the samples and took the pictures.

The collection method is destructive and consists in scraping off all organisms from a $20 \times 20 \mathrm{~cm}\left(400 \mathrm{~cm}^{2}\right)$ quadrat with a hammer and a chisel. Two replicates were obtained per season and depth, which provide a sampling area large enough to be considered as representative of most Mediterranean rocky bottom assemblages (Coppejans 1980, Verlaque 1987, Ballesteros 1992). Samples were sealed in individual plastic bags and fixed in $4 \%$ formalin:sea water for later sorting and classification in the laboratory. The abundance of algal species and invertebrates was quantified as biomass ( $\mathrm{g} \mathrm{dw}$ ) after drying at $60^{\circ} \mathrm{C}$ until constant weight (generally for 24-48 h). Since crustose corallines were completely destroyed during sampling and it was not possible to measure the dry weight, we estimated in situ the coverage of the different species. The biomass was calculated from coverage data using the conversion factors in Ballesteros (1992).

The in situ visual method is direct and nondestructive. Species abundance was measured in situ with a $25 \times 25 \mathrm{~cm}\left(625 \mathrm{~cm}^{2}\right)$ quadrat divided into 25 sub-squares of $5 \times 5 \mathrm{~cm}^{2}$. The presence or absence of each species was recorded within each sub-square and the total abundance was calculated as the percentage of sub-squares in which a species was present (Ballesteros 1996, Cebrian and Ballesteros 2004, Tomas et al. 2011). Small samples of unidentified species were collected and later identified in the laboratory. Four relevés were obtained per season and depth, covering an area considered as representative of Mediterranean rocky bottom assemblages (Sala and Ballesteros 1997, Cebrian et al. 2000).

The photoquadrat method is indirect and non-destructive. Photos of the assemblages were used to estimate the coverage area of the different species. Pictures were taken with a Nikonos $\mathrm{V}$ camera equipped with a $28 \mathrm{~mm}$ UW Nikkor objective, a close-up Nikonos lens and a Nikon SB-105 flash (Martí et al. 2004a, b). Each frame recorded an area covering $310 \mathrm{~cm}^{2}$. Seaweeds and invertebrates in each frame were projected on an inverse slide projector and species patches were manually outlined on acetate sheets. They were then digitalized, and the total area covered by each species was calculated using Adobe Photoshop 5.0 software. In some cases, various small species grew tightly together, making turf and individual identification impossible. Up to nine different turf categories were identified according to their qualitative composition, obtained with the collection method samples. Eight pictures were taken at each depth and in each season, covering an area largely representative of Mediterranean rocky benthic communities (Martí et al. 2004b, Kipson et al. 2011).

\section{Statistical analyses}

The three sampling methods were compared through three descriptors of community structure (species richness, species diversity and quantitative similarity between samples) using abundance data. Descriptors were calculated using replicates, which vary with each method (collection method, 2 replicates $=800 \mathrm{~cm}^{2}$; in situ visual method, 4 replicates $=2500 \mathrm{~cm}^{2}$; photoquadrat method, 8 replicates $=2480 \mathrm{~cm}^{2}$ ). Consequently, we compared the information obtained using the areas that were considered as representative for each sampling method, not the same areas, as it would be too timeconsuming to collect, identify and quantify everything present in areas of e.g. $2500 \mathrm{~cm}^{2}$.

Species richness per assemblage $(\mathrm{N})$ was calculated as the total number of species merging all replicates for each season and depth. Species diversity was estimated with the Shannon Index (H', Shannon 1948) formula recommended by Margalef (1974). Species abundance 
$\left(\mathrm{p}_{\mathrm{i}}\right)$ was measured as biomass (the collection method), species frequency (the in situ visual method) or species coverage (the photoquadrat method). Finally, the quantitative similarity between samples was calculated with the Kulczynski Index (Kulczynski 1927). Similarity was calculated between pairs of sample groups of increasing replicate number, that is, of increasing sampling area. Similarity could only be calculated between the two existing samples (pairs of one replicate, comparison of sampling areas of $400 \mathrm{~cm}^{2}$ ) for the collection method. The similarity was calculated between pairs of one (comparison of sampling areas of $625 \mathrm{~cm}^{2}$ ) and two (comparison of sampling areas of $1250 \mathrm{~cm}^{2}$ ) replicates for the in situ visual method. The similarity was calculated between pairs of one (comparison of sampling areas of $310 \mathrm{~cm}^{2}$ ), two (comparison of sampling areas of $620 \mathrm{~cm}^{2}$ ), three (comparison of sampling areas of $930 \mathrm{~cm}^{2}$ ) and four (comparison of sampling areas of $1240 \mathrm{~cm}^{2}$ ) replicates for the photoquadrat method. The mean of the Kulczynski index was calculated for all possible combinations of replicates of each size with a program written in Turbo Pascal.

The qualitative similarity among methods was calculated with the Jaccard Index (Jaccard 1901) using the detected species presence. The qualitative similarity of the in situ visual and the photoquadrat methods was compared with the collection method, which is the method that detects the largest number of species. The average time cost of each method was calculated considering the same experienced divers and taxonomic specialists.

The ordination of species in space (depth) and time (seasons) for each sampling method was analysed with canonical correspondence analysis (CCA) and the relevance of each factor was estimated with partial CCAs. The relevance of the method factor, as well as space and time, were analysed with a CCA and partial CCAs including all three data sets. Only the 68 species common to the three methods were included and the abundances were all transformed to a 0-100 scale. We selected unimodal methods because a preliminary detrended correspondence analysis showed that the gradient length (SD) was higher than would be the case for a complete species turnover (4.0 SD, Legendre and Legendre 1998). Multivariate analyses were performed with the software CANOCO 4.0 (ter Braak and Smilauer 1998).

\section{RESULTS}

A total of 262 species were identified in the 40 samples obtained with the collection method (Fig. 1, Supplementary Material Table S1). The total number of species increased along the depth gradient (Fig. 2A), A50 being almost twice as rich as the shallow-water communities A0 and A4. This increase in species richness was mainly due to the proliferation of small red algae and animals distinctive from the coralligenous environment (A50). Species richness was higher in autumn-winter than in spring-summer, except in A12, which showed a summer maximum (Supplementary Material Table S4). The highest seasonal change in

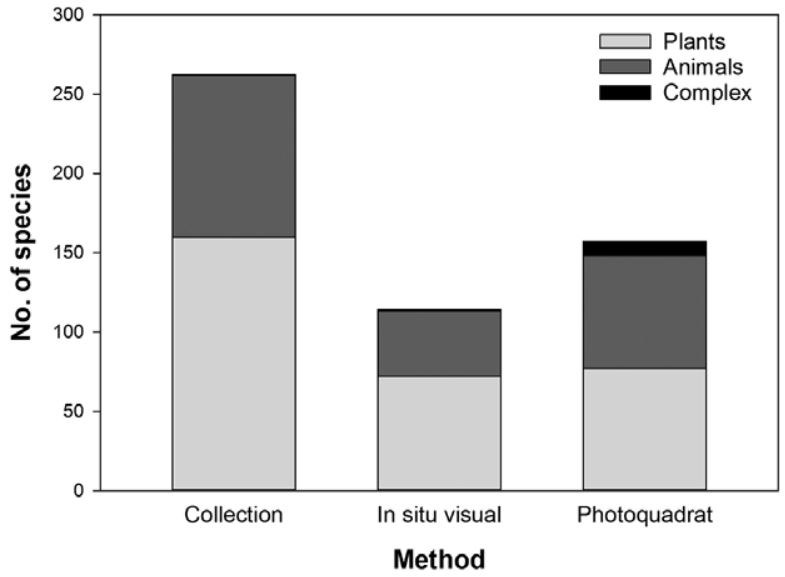

Fig. 1. - Total number of species identified with each method. The term "complex" stands for a turf of intermingled filamentous algae and invertebrates (mainly hydrozoans and bryozoans).

species richness corresponded to A4, with a coefficient of variation of $26.4 \%$ (Table S4). In contrast, A50 was the assemblage with the lowest seasonal change in species richness, with a coefficient of variation of $7.5 \%$ (Table S4).

A total of 114 species were identified in the 80 samples obtained with the in situ visual method (Fig. 1, Supplementary Material Table S2). The total number of species decreased along the depth gradient (Fig. 2A), contrasting with the results obtained with the collection method. Maximum species richness was observed in winter and minimum in spring-summer (Table S4). The highest seasonal change in species richness corresponded to $\mathrm{A} 50$, with a coefficient of variation of $28.9 \%$ (Table S4). In contrast, A25 was the assemblage with the lowest seasonal change in species richness, with a coefficient of variation of $14.6 \%$ (Table S4).

A total of 160 different species or categories were identified in the 160 frames obtained with the photoquadrat method (Fig. 1, Supplementary Material Table S3). Most of the categories (148) were identified at a species level, 9 corresponded to different kinds of turfs and 3 corresponded to unidentified entities (e.g. dark patches or bare rock without living organisms). This method detected a remarkably low species richness for the strongly multilayered assemblage A0 (Fig. 2A). The total number of species increased along the depth gradient (Fig. 2A), the maximum being at A50, as observed with the collection method. Species richness was generally higher in autumn-winter than in springsummer (Table S4). Seasonal differences in species richness were evident for $\mathrm{A} 0$ and $\mathrm{A} 25$, with a coefficient of variation of $52.2 \%$ and $35.9 \%$, respectively (Table S4). In contrast, A4 and A12 had small seasonal changes in species richness, with a coefficient of variation of $9.6 \%$ and $9.7 \%$, respectively (Table S4).

Species diversity, measured with the Shannon Index $\left(H^{\prime}\right)$, tended to increase along the depth gradient with the collection method (Fig. 2B). The seasonal variation of H' using this method was notable but no general patterns arose among the different assemblages (Table S4). The in situ visual method provided higher estimates of species diversity than the collection 

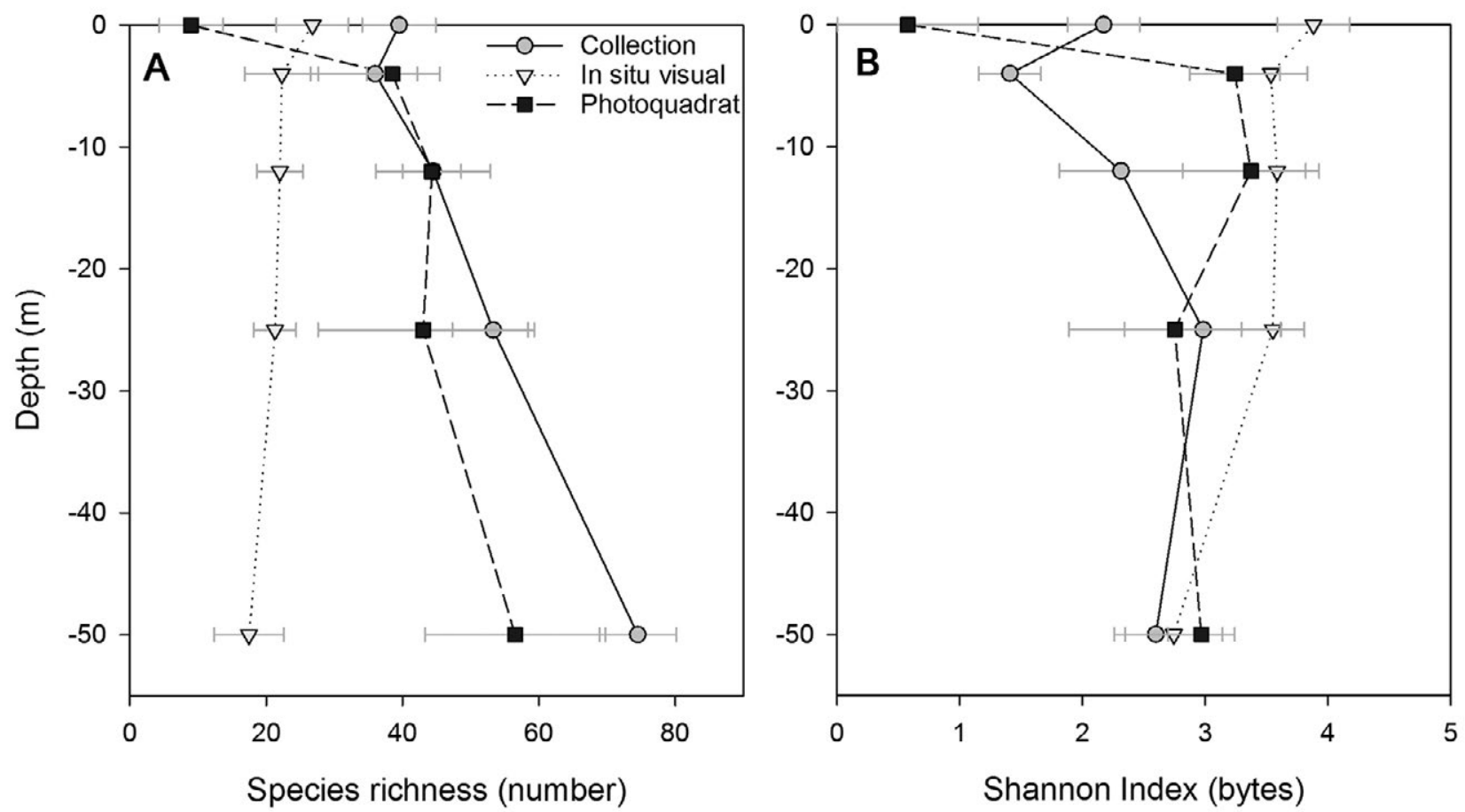

Fig. 2. - Average number of species (A) and species diversity (B) along the depth gradient.

Table 1. - Quantitative similarity index (Kulczynski Index) between samples. Estimates show mean \pm sd. Group size indicates the number of replicates per group used to calculate the similarity index.

\begin{tabular}{|c|c|c|c|c|c|c|c|}
\hline Method & Season & Group size & $0 \mathrm{~m}$ & $4 \mathrm{~m}$ & $12 \mathrm{~m}$ & $25 \mathrm{~m}$ & $50 \mathrm{~m}$ \\
\hline \multirow[t]{4}{*}{ Collection } & spring & 1 & 0.78 & 0.74 & 0.44 & 0.76 & 0.44 \\
\hline & summer & 1 & 0.80 & 0.75 & 0.52 & 0.66 & 0.32 \\
\hline & autumn & 1 & 0.84 & 0.85 & 0.46 & 0.25 & 0.46 \\
\hline & winter & 1 & 0.69 & 0.88 & 0.82 & 0.62 & 0.27 \\
\hline \multirow[t]{8}{*}{ In situ visual } & spring & 1 & $0.71 \pm 0.06$ & $0.74 \pm 0.06$ & $0.66 \pm 0.08$ & $0.65 \pm 0.06$ & $0.69 \pm 0.06$ \\
\hline & & 2 & $0.78 \pm 0.02$ & $0.82 \pm 0.04$ & $0.75 \pm 0.02$ & $0.73 \pm 0.01$ & $0.75 \pm 0.06$ \\
\hline & summer & 1 & $0.48 \pm 0.09$ & $0.67 \pm 0.09$ & $0.72 \pm 0.04$ & $0.58 \pm 0.05$ & $0.79 \pm 0.03$ \\
\hline & & 2 & $0.60 \pm 0.06$ & $0.77 \pm 0.07$ & $0.79 \pm 0.05$ & $0.68 \pm 0.00$ & $0.81 \pm 0.02$ \\
\hline & autumn & 1 & $0.77 \pm 0.04$ & $0.76 \pm 0.02$ & $0.71 \pm 0.06$ & $0.63 \pm 0.09$ & $0.59 \pm 0.12$ \\
\hline & & 2 & $0.82 \pm 0.01$ & $0.81 \pm 0.01$ & $0.78 \pm 0.02$ & $0.70 \pm 0.02$ & $0.69 \pm 0.06$ \\
\hline & winter & 1 & $0.77 \pm 0.04$ & $0.76 \pm 0.06$ & $0.73 \pm 0.08$ & $0.65 \pm 0.06$ & $0.70 \pm 0.07$ \\
\hline & & 2 & $0.83 \pm 0.05$ & $0.82 \pm 0.01$ & $0.80 \pm 0.03$ & $0.73 \pm 0.03$ & $0.78 \pm 0.05$ \\
\hline \multirow[t]{16}{*}{ Photoquadrat } & spring & 1 & $0.92 \pm 0.08$ & $0.48 \pm 0.16$ & $0.51 \pm 0.15$ & $0.70 \pm 0.13$ & $0.36 \pm 0.26$ \\
\hline & & 2 & $0.93 \pm 0.04$ & $0.58 \pm 0.11$ & $0.61 \pm 0.10$ & $0.77 \pm 0.09$ & $0.50 \pm 0.17$ \\
\hline & & 3 & $0.94 \pm 0.02$ & $0.64 \pm 0.09$ & $0.67 \pm 0.07$ & $0.81 \pm 0.08$ & $0.56 \pm 0.13$ \\
\hline & & 4 & $0.94 \pm 0.02$ & $0.68 \pm 0.08$ & $0.70 \pm 0.06$ & $0.84 \pm 0.08$ & $0.61 \pm 0.11$ \\
\hline & summer & 1 & $0.97 \pm 0.02$ & $0.47 \pm 0.15$ & $0.67 \pm 0.07$ & $0.63 \pm 0.16$ & $0.43 \pm 0.20$ \\
\hline & & 2 & $0.97 \pm 0.01$ & $0.60 \pm 0.11$ & $0.75 \pm 0.05$ & $0.72 \pm 0.10$ & $0.56 \pm 0.14$ \\
\hline & & 3 & $0.98 \pm 0.01$ & $0.67 \pm 0.09$ & $0.79 \pm 0.04$ & $0.76 \pm 0.09$ & $0.62 \pm 0.11$ \\
\hline & & 4 & $0.98 \pm 0.01$ & $0.71 \pm 0.08$ & $0.82 \pm 0.03$ & $0.79 \pm 0.07$ & $0.66 \pm 0.10$ \\
\hline & autumn & 1 & $0.85 \pm 0.06$ & $0.52 \pm 0.16$ & $0.58 \pm 0.13$ & $0.65 \pm 0.09$ & $0.48 \pm 0.26$ \\
\hline & & 2 & $0.89 \pm 0.04$ & $0.61 \pm 0.10$ & $0.67 \pm 0.08$ & $0.74 \pm 0.06$ & $0.58 \pm 0.15$ \\
\hline & & 3 & $0.91 \pm 0.03$ & $0.65 \pm 0.07$ & $0.72 \pm 0.06$ & $0.78 \pm 0.05$ & $0.64 \pm 0.11$ \\
\hline & & 4 & $0.92 \pm 0.02$ & $0.68 \pm 0.05$ & $0.75 \pm 0.04$ & $0.81 \pm 0.04$ & $0.68 \pm 0.10$ \\
\hline & winter & 1 & $0.95 \pm 0.02$ & $0.48 \pm 0.14$ & $0.52 \pm 0.10$ & $0.61 \pm 0.07$ & $0.46 \pm 0.20$ \\
\hline & & 2 & $0.96 \pm 0.02$ & $0.60 \pm 0.09$ & $0.64 \pm 0.07$ & $0.70 \pm 0.05$ & $0.58 \pm 0.12$ \\
\hline & & 3 & $0.97 \pm 0.01$ & $0.66 \pm 0.06$ & $0.70 \pm 0.06$ & $0.75 \pm 0.04$ & $0.64 \pm 0.09$ \\
\hline & & 4 & $0.97 \pm 0.01$ & $0.69 \pm 0.05$ & $0.73 \pm 0.05$ & $0.77 \pm 0.03$ & $0.68 \pm 0.08$ \\
\hline
\end{tabular}

method (Fig. 2B), probably because of the intrinsic equitability of the in situ visual method abundances. The average species diversity per assemblage was always H'>2.7 bits with the in situ visual method. The in situ visual method seasonal variation was low and general patterns were not found among the different assemblages (Table S4). The photoquadrat method also provided higher estimates of species diversity than the collection method and similar ones to the in situ visual method (Fig. 2B), H'>2.7 bits except in the strongly multilayered A0 assemblage. The seasonal variation of H' calculated with the photoquadrats was noteworthy, especially for A0 (99.3\% of CV), and species diversity tended to be higher in winter for all assemblages except A0 (Table S4).

The quantitative similarity between samples, measured with the Kulczynski Index, was calculated by comparing sampling areas of $400 \mathrm{~cm}^{2}$ (pairs of 
Table 2. - Number of samples (n) and sampling area $\left(\mathrm{cm}^{2}\right)$ to obtain a Kulczynski Index of K $\geq 0.7$ for each method and depth. The season with the lowest similarity value was used as a reference.

\begin{tabular}{|c|c|c|c|c|c|c|c|c|c|c|}
\hline \multirow{2}{*}{$K \geq 0.7$} & \multicolumn{2}{|c|}{$\mathrm{A} 0$} & \multicolumn{2}{|c|}{ A4 } & \multicolumn{2}{|c|}{ A12 } & \multicolumn{2}{|c|}{ A25 } & \multicolumn{2}{|c|}{ A50 } \\
\hline & $\mathrm{n}$ & $\mathrm{cm}^{2}$ & $\mathrm{n}$ & $\mathrm{cm}^{2}$ & $\mathrm{n}$ & $\mathrm{cm}^{2}$ & $\mathrm{n}$ & $\mathrm{cm}^{2}$ & $\mathrm{n}$ & $\mathrm{cm}^{2}$ \\
\hline Collection & 1 & 400 & 1 & 400 & $>1$ & $>400$ & $>1$ & $>400$ & $>1$ & $>400$ \\
\hline In situ visual & $>2$ & $>1250$ & 2 & 1250 & 2 & 1250 & $>2$ & $>1250$ & $>2$ & $>1250$ \\
\hline Photoquadrat & 1 & 310 & $>4$ & $>1240$ & 4 & 1240 & 2 & 620 & $>4$ & $>1240$ \\
\hline
\end{tabular}

one replicate) for the collection method. This method yielded high similarity values $(\geq 0.7)$ for A0 and A4 all year round, indicating high homogeneity between samples (Table 1). Similarity decreased and changed between seasons for A12 and A25 (Table 1). A50 exhibited the lowest similarity in each season (Table 1). The Kulczynski Index estimated with the in situ visual method and comparing sampling areas of 625 $\mathrm{cm}^{2}$ (pairs of one replicate) resulted in high similarity values, generally higher than or equal to 0.7 (Table $1)$. The similarity values increased even more when comparing sampling areas of $1250 \mathrm{~cm}^{2}$ (pairs of two replicates, Table 1). The Kulczynski Index estimated with the photoquadrat method and comparing sampling areas of $310 \mathrm{~cm}^{2}$ (pairs of one replicate) resulted in extremely high similarity values for A0, intermediate values for A25 and rather low values for A4, A12 and A50 (Table 1). The similarity values increased gradually when comparing increasing sampling areas of $620 \mathrm{~cm}^{2}$ (pairs of two replicates), $930 \mathrm{~cm}^{2}$ (pairs of three replicates) and $1240 \mathrm{~cm}^{2}$ (pairs of four replicates, Table 1).

To sum up, for the areas sampled in each methodology, the photoquadrat method detected a similar species richness per assemblage to the collection method (except for the strongly multilayered A0 assemblage), though the total number of species identified with the photoquadrat method was only $61 \%$ of that identified with the collection method. The in situ visual method detected much lower species richness than the collection and photoquadrat methods. Species diversity estimates were the highest with the in situ visual method and the lowest with the collection method, but differences decreased along the depth gradient and all three H' converged at A50. Both the collection and photoquadrat methods were able to detect a higher seasonal variability of species diversity than the in situ visual method. The number of replicates and sampling area needed to obtain a good homogeneity level (Kulczynski Index $\geq 0.7$ ) changed among methods and assemblages (Table 2). For example, one sample of $400 \mathrm{~cm}^{2}$ was enough for the collection method, a sampling area of $625 \mathrm{~cm}^{2}$ was enough for the in situ visual method, and more than four photoquadrat samples $\left(>1240 \mathrm{~cm}^{2}\right)$ were needed to obtain a good similarity for A4 (Table 2).

The collection method has been used as a reference to calculate qualitative similarity (Jaccard Index) with the other two methods (Fig. 3). The qualitative similarity between the collection and photoquadrat methods was low and decreased along the depth gradient (Fig. $3 \mathrm{~A})$. The qualitative similarity between the collection and photoquadrat methods was also low, especially for the strongly multilayered A0 (Fig. 3B); in that case the dense canopy of Cystoseira stricta (A0) hid most or all species of the other layers, resulting in an extremely low species detection.

Partial CCAs showed that space (depth) explained about twice as much variance as time (season) for all three methods. Depth explained 21\%, 22\% and $18 \%$ of the variance and season explained $10 \%, 12 \%$ and $9 \%$ of the variance for the collection, in situ visual and photoquadrat methods, respectively. Shared variance between depth and season was really low $(<0.1 \%)$ for all methods. When the three data sets were merged, partial CCA showed that space (depth) explained $16.0 \%$ of the variance, being the main factor explaining species distribution, and it was strongly associated with the CCA first axis (CCA1, Fig. 4). More differences were due to the method used $(7.9 \%$ of explained variance) than to time (season explained $5.8 \%$ of the variance). Sampling method correlated well with the CCA second axis (CCA2, Fig. 4A and B) and clearly separated the collection method from the in situ visual and photoquadrat methods. A season gradient was observed along the CCA third axis (CCA3, Fig. 4C and D) segregating the spring and winter samples. CCA3 also separated the photoquadrat method samples from the samples of the other two methods. The total variance explained by the three factors was $29.8 \%$ and the shared variance was low (0.2).

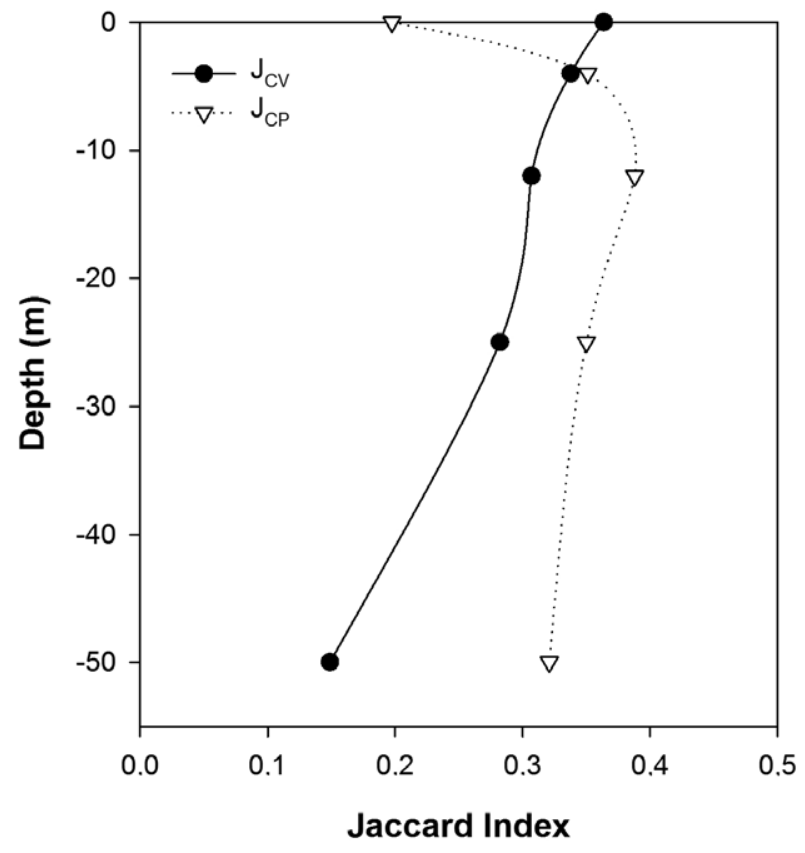

Fig. 3. - Qualitative similarity (Jaccard Index, J) between methods along the depth gradient: between the collection method and the in situ visual method $\left(\mathrm{J}_{\mathrm{CV}}\right)$ and between the collection method and the photoquadrat method $\left(\mathrm{J}_{\mathrm{CP}}\right)$. 

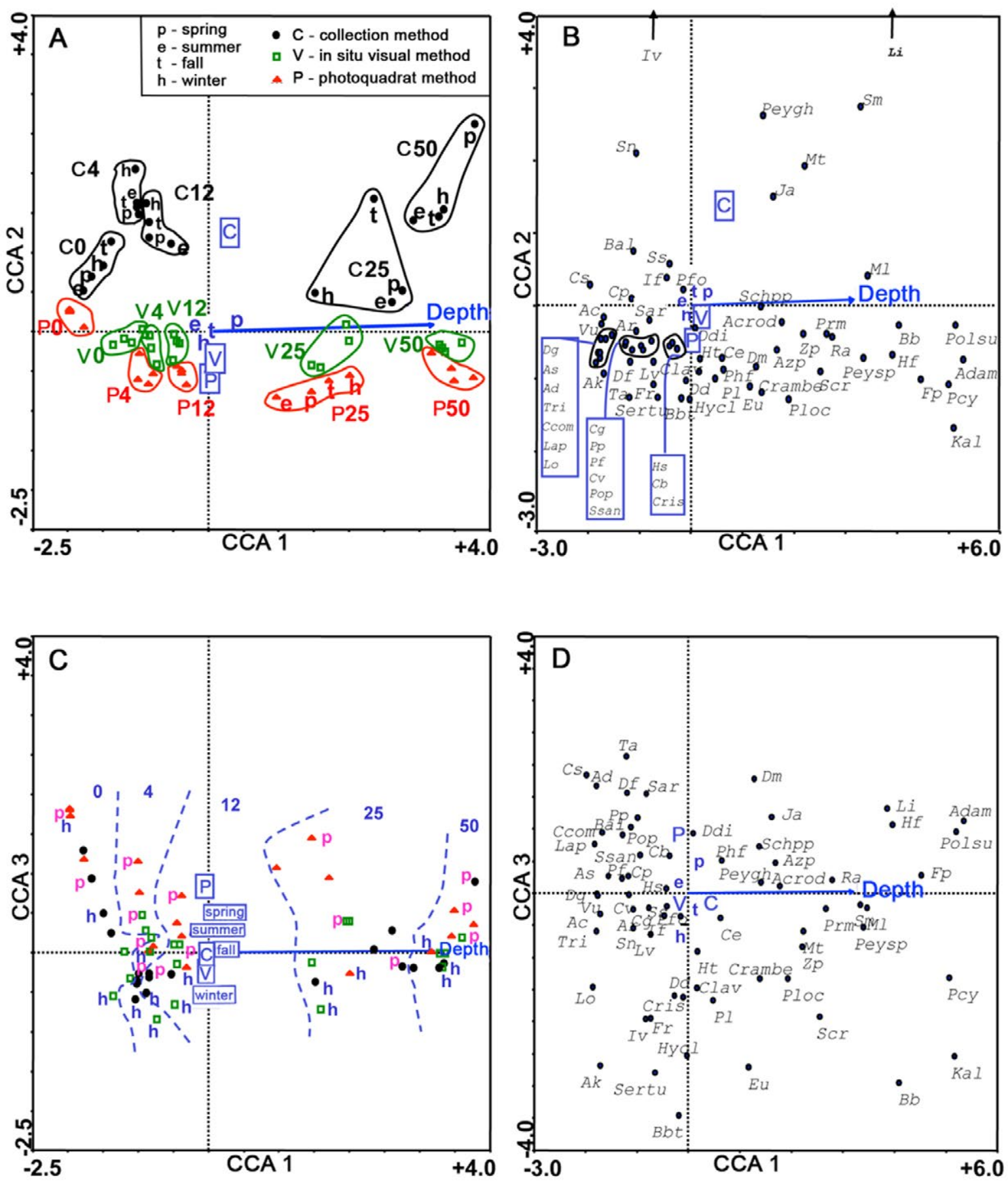

Fig. 4 - Ordination of the first three axes of the canonical correspondence analysis. A and C show sample ordination; B and D show species ordination. Numbers correspond to the depth in $\mathrm{m}$. For example, $\mathrm{C} 0$ are replicates of the collection method (C) at $0 \mathrm{~m}$ deep and V50 are replicates of the photoquadrat method at $50 \mathrm{~m}$ deep. Species abbreviation as in Supplementary Material Tables S1, S2 and S3.

\section{DISCUSSION}

\section{Cost comparison}

The costs of the equipment used in this study are relatively low when compared with those of other sampling underwater devices, such as remotely operated vehicles or submersibles. However, in marine environments, an important fraction of the cost is due to time used in sample collection and processing. Diving time is one of the main limiting factors when sampling benthic communities. This limitation mainly affects the collection and in situ visual methods, which are more time-consuming than the photoquadrat method (Table 3 ). The collection and photoquadrat methods require a considerable time cost in the laboratory to identify and quantify species (Table 3). The total time cost per area considered to be representative for each method is the highest for the collection method, intermediate for the photoquadrat method and the lowest for the in 
Table 3. - Comparison of the cost and requirements of the three methods studied.

\begin{tabular}{lccc}
\hline & Collection method & In situ visual method & Photoquadrat method \\
\hline Time cost & $33.5 \mathrm{~h}$ & $1.25 \mathrm{~h}$ & $6.25 \mathrm{~h}$ \\
Replicates, total area & $\mathrm{n}=2,800 \mathrm{~cm}^{2}$ & $\mathrm{n}=4,2500 \mathrm{~cm}^{2}$ & $\mathrm{n}=8,2480 \mathrm{~cm}^{2}$ \\
Diving time & $30 \mathrm{~min}$ & $45 \mathrm{~min}$ & $15 \mathrm{~min}$ \\
Lab time & $33 \mathrm{~h}$ & $30 \mathrm{~min}$ & $6 \mathrm{~h}$ \\
Working time per $1000 \mathrm{~cm}^{2}$ & $42 \mathrm{~h}$ & $30 \mathrm{~min}$ & $2.5 \mathrm{~h}$ \\
Equipment cost & Medium & Low & Medium \\
Diver skill requirements & Experienced diver & Experienced diver and taxonomic specialist & Experienced diver \\
Obtained information & & & Hedium \\
Objectivity & High & Low & Medium \\
Resolution & High & Medium & Medium \\
Adequacy & Small & Yes & Yes \\
Surface of study & No & Yes & No \\
Long-term studies & Yes & No & Yes \\
Multilayered assemblages & Yes & Yes & Yes \\
Deep assemblages $(>50 \mathrm{~m})$ & Yes & Yes & Yes \\
Bathymetric studies & Yes & No & Yes \\
Seasonal studies & Yes & & \\
Permanent record & & & \\
\hline
\end{tabular}

situ visual method (Table 3), as observed for Atlantic assemblages (Mantelatto et al. 2013).

The collection method is limited by both diving and laboratory time. Moreover, the sampled surface is smaller than in the other two methods, resulting in a high time cost per equivalent area and making this method suitable for working at small scales. However, the collection method is the only self-sufficient method, as the other two methods need to take extra samples to identify the unknown species in the field. In contrast, working effort for the in situ visual method is much lower and is mainly due to diving time (Table 3 ). The real limitation of the in situ visual method is finding an expert diver who is also an expert specialist of taxonomic groups so that the taxonomic resolution is high enough. The photoquadrat method is the fastest and simplest in the field but the time processing the images in the laboratory varies widely up to several hours per frame for complex communities (Whorff and Griffing 1992 and pers. obs.). The in situ visual and the photoquadrat methods are non-destructive, so they are suitable for long-term monitoring (e.g. Wethey 1984, Garrabou et al. 2002, Teixido et al. 2011), while the collection method is not as appropriate as it destroys the area of the assemblage that is sampled.

\section{Balance between time cost and information quality}

The information quality and suitability of each method are summarized in Table 3. The high time cost of the collection method is compensated with high-precision results: a large number of accurately identified and quantified species.

In contrast, the in situ visual method is fast but provides a much lower resolution. In fact it only detects $43 \%$ of the species detected with the collection method and the abundance data obtained are more discrete and homogeneous (ranging from 0 when a species is not present to 25 when a species is present in all sub-quadrats, which represent a two-fold range) than biomass or coverage data (a six-fold range). Consequently, information is simplified and diversity estimates are affected. A similar in situ visual method can be performed by estimating the percent cover of species in each sub-square ( 5 classes) and then summing scores across the 25 sub-squares (Bianchi et al. 2004). This cover estimation technique provides less discrete and homogeneous data than the frequency count technique. However, Parravicini et al. (2010) revealed that both techniques show the same patterns of community variation but the classical cover estimation technique is largely more time-consuming. The in situ visual method is also the most subjective as the experience and taxonomical knowledge of the diver plays an important role in the quality of the results (Meese and Tomich 1992, Dethier et al. 1993). Information quality decreases with depth and the method is not recommended at depths of $50 \mathrm{~m}$ or deeper. The loss of precision of the in situ visual method with depth seems to be related to the increasing difficulty of recognizing species in situ because of nitrogen narcosis, reduced light and cold. The advantages of the in situ visual method are the fast and in situ data availability and the fact that it is nondestructive, which may compensate for the drawbacks in some studies.

The photoquadrat method has an intermediate time cost and resolution (it detects $60 \%$ of the species detected with the collection method). Photo digitalization is more objective than in any other direct method (Meese and Tomich 1992). However it is not appropriate for multilayered assemblages (as observed by Foster et al. 1991, Meese and Tomich 1992 and Whorff and Griffing 1992), as it only accounts for the overstory. The advantages of the photoquadrat method are that the experienced divers and taxonomic specialists can be different operators (as in the collection method), it is non-destructive and it offers a permanent record.

The quantification estimates of some organisms change between methods. For example, crustose species of the understory have higher estimates with the collection (biomass) and the in situ visual (abundance) method than with the photoquadrat (coverage) method. This may lead to contradictory results between methods, as observed with the specific diversity of assemblage A4. A4 assemblage was dominated by the crustose calcified coralline alga Neogoniolithon brassica-florida, with some brown annual algae (e.g. Dictyota fasciola and Padina pavonica) growing in the overstory. $\mathrm{Ne}$ - 
ogoniolithon brassica-florida strongly dominates in terms of biomass, resulting in low estimates of species diversity using the collection method. In contrast, the photoquadrat method underestimates Neogoniolithon brassica-florida coverage, resulting in a higher specific diversity than in the collection method. Another example is the tendency of the in situ visual method to overestimate small but visible epiphytes with low biomass, such as the tetrasporophytes of the red alga Asparagopsis taxiformis.

All three methods similarly detect spatial and temporal variability of the data. Independently of the sampling method, the main species distribution and abundance pattern is always related to the depth gradient. The three methods are good and consistent for detecting species changes along the bathymetric axis. However, differences due to the sampling method are greater than differences due to temporal variability. The three methods are inconsistent in detecting the small-scale seasonal changes, probably because of the combined limitations discussed above (overestimation or underestimation of specific groups, reduction in information quality with depth or in multilayered communities, and homogeneous abundance data).

In conclusion, all three methods are valid for studying rocky benthic assemblages but their specific limitations must always be taken into account. The staff and resource availability, the assemblage type, the working scale and the objectives of each particular study are other aspects to consider when choosing the most appropriate sampling method. For instance, the collection method is the best when high accuracy is needed; the in situ visual method provides fast results; and photoquadrats provide a permanent record that can always be revisited and used for different objectives.

\section{ACKNOWLEDGEMENTS}

Xavier Turon provided the Turbo Pascal program to calculate similarities. Funding to NS was partially provided by the "Comissionat per a Universitat i Recerca de la Generalitat de Catalunya". This paper is a contribution of the CSIC INTRAMURAL project reference $201330 \mathrm{E} 065$.

\section{REFERENCES}

Airoldi L., Rindi F., Cinelli F. 1995. Structure, seasonal dynamics and reproductive phenology of a filamentous turf assemblage on a sediment influenced, rocky subtidal shore. Bot. Mar. 38: $227-237$.

https://doi.org/10.1515/botm.1995.38.1-6.227

Ballesteros E. 1992. Els vegetals i la zonació litoral: espècies, comunitats i factors que influeixen en la seva distribució. Institut d'Estudis Catalans, Barcelona, 616 pp.

Ballesteros E. 1996. Un método rápido y efectivo para la elaboración de inventarios en el bentos marino sobre sustrato rocoso. Algas 16: 8-9

Ballesteros E., Sala E., Garrabou J., et al. 1998. Community structure and frond size distribution of a deep water stand of Cystoseira spinosa (Phaeophyta) in the northwestern Mediterranean. Eur. J. Phycol. 33: 121-128. https://doi.org/10,1080/09670269810001736613

Bellan-Santini D. 1963. Méthode de récolte et d'étude quantitative des peuplements sur substrat dur dans la zone d'agitation hydrodynamique. CIESMM, Coll. Benthos. Méthodes quant. échel. dimension. Benthontes, pp. 23-24.

Benedetti-Cecchi L., Airoldi L., Abbiati M., et al. 1996. Estimating the abundance of benthic invertebrates: A comparison of procedures and variability between observers. Mar. Ecol. Prog. Ser. 138: 93-101. https://doi.org/10.3354/meps 138093

Bertocci I., Araujo R., Incera M., et al. 2012. Benthic assemblages of rock pools in northern Portugal: seasonal and between-pool variability. Sci. Mar. 76: 781-789. https://doi.org/10.3989/scimar.03669.21A

Bianchi C.N., Pronzato R., Cattaneo-Vietti R., et al. 2004. Mediterranean marine benthos: a manual of methods for its sampling and study. Hard bottoms. Biol. Mar. Mediter. 11: 185-215.

Boudouresque C.F. 1971. Méthodes d'étude qualitative et quantitative du benthos (en particulier du phytobenthos). Téthys 3: 79-104.

Bussotti S., Terlizzi A., Fraschetti S., et al. 2006. Spatial and temporal variability of sessile benthos in shallow Mediterranean marine caves. Mar. Ecol. Prog. Ser. 325: 109-119. https://doi.org/10.3354/meps325109

Calvin N.I., Ellis R.J. 1978. Quantitative and qualitative observations on Laminaria dentigera and other subtidal kelps of Southern Kodiak Island, Alaska. Mar. Biol. 47: 331-336. https://doi.org/10.1007/BF00388924

Cebrian E., Ballesteros E. 2004. Zonation patterns of benthic communities in an upwelling area from the western Mediterranean (La Herradura, Alboran Sea). Sci. Mar. 68: 69-84. https://doi.org/10.3989/scimar.2004.68n169

Cebrian E., Ballesteros E., Canals M. 2000. Shallow rocky bottom benthic assemblages as calcium carbonate producers in the Alboran Sea (southwestern Mediterranean). Oceanol. Acta 23: 311-322. https://doi.org/10.1016/S0399-1784(00)00131-6

Coppejans E. 1980. Phytosociological studies of Mediterranean algal vegetation: rocky surfaces of the photophilic infralittoral zone. In: Price J.H., Irvine D.E.G., Farnham W.F. (eds), The Shore Environment. Academic Press, London, pp. 371-393.

Dayton P.K. 1971. Competition, disturbance and community organization: provision and subsequent utilization of space in a rocky intertidal community. Ecol. Monogr. 41: 351-389. https://doi.org/10.2307/1948498

Deter J., Descamp P., Boissery P., et al. 2012. A rapid photographic method detects depth gradient in coralligenous assemblages. J. Exp. Mar. Biol. Ecol. 418: 75-82. https://doi.org/10.1016/j.jembe.2012.03.006

Dethier M.N., Graham E.S., Cohen S., et al. 1993. Visual versus random-point percent cover estimations: objective is not always better. Mar. Ecol. Prog. Ser. 96: 93-100. https://doi.org/10.3354/meps096093

Foster M.S., Harrold C., Hardin D.D. 1991. Point vs. photo quadrat estimates of the cover of sessile marine organisms. J. Exp. Mar. Biol. Ecol. 146: 193-203. https://doi.org/10.1016/0022-0981(91)90025-R

Garrabou J. 1999. Life-history traits of Alcyonium acaule and Parazoanthus axinellae (Cnidaria, Anthozoa), with emphasis on growth. Mar. Ecol. Prog. Ser. 178: 193-204. https://doi.org/10.3354/meps 178193

Garrabou J., Riera J., Zabala M. 1998. Landscape pattern indices applied to Mediterranean subtidal rocky benthic communities. Landscape Ecol. 13: 225-247. https://doi.org/10.1023/A:1007952701795

Garrabou J., Ballesteros E., Zabala M. 2002. Structure and dynamics of north-western Mediterranean rocky benthic communities along a depth gradient. Estuar. Coast. Shelf Sci. 55: 493-508. https://doi.org/10.1006/ecss.2001.0920

Gunnill F.C. 1980. Recruitment and standing stock in populations of one green alga and five brown algae in the intertidal zone near La Jolla, California during 1973-1977. Mar. Ecol. Prog. Ser. 3: 231-243. https://doi.org/10.3354/meps003231

Hughes T.P., Jackson J.B.C. 1985. Population-dynamics and life histories of foliaceous corals. Ecol. Monogr. 55: 141-166. https://doi.org/10.2307/1942555

Jaccard P. 1901. Distribution de la flore alpine dans le bassin des Dranses et dans quelques régions voisines. Bull. Soc. Vaud. Sci. Nat. 37: 241-272.

John D.M., Lieberman D., Lieberman M. 1977. Quantitative study of structure and dynamics of benthic subtidal algal vegetation in Ghana (Tropical West-Africa). J. Ecol. 65: 497-521. https://doi.org/10.2307/2259497 
Kipson S., Fourt M., Teixido N., et al. 2011. Rapid biodiversity assessment and monitoring method for highly diverse benthic communities: A case study of Mediterranean coralligenous outcrops. PLoS ONE 6: e27103. https://doi.org/10.1371/journal.pone.0027103

Kulczynski S. 1927. Die Pflanzenassoziationen der Pieninen. Bull. Int. Acad. Po. Sci. Lett., Cl. Sci. Math. Nat. 2: 57-203.

Legendre P., Legendre L. 1998. Numerical Ecology. Elsevier Science B.V., Amsterdam, 853 pp.

Littler M.M., Littler D.S. 1985. Handbook of phycological methods. Ecological field methods: Macroalgae. Cambridge University Press, Cambridge, 632 pp.

Mann K.H. 1972. Ecological energetics of seaweed zone in a marine bay on Atlantic coast of Canada. II. Productivity of seaweeds. Mar. Biol. 14: 199-209.

Mantelatto M.C., Fleury B.G., Menegola C., et al. 2013. Costbenefit of different methods for monitoring invasive corals on tropical rocky reefs in the southwest Atlantic. J. Exp. Mar. Biol. Ecol. 449: 129-134. https://doi.org/10.1016/j.jembe.2013.09.009

Margalef R. 1974. Ecología. Ediciones Omega, Barcelona, 951 pp.

Martí R., Uriz M.J., Ballesteros E., et al. 2004a. Benthic assemblages in two Mediterranean caves: species diversity and coverage as a function of abiotic parameters and geographic distance. J. Mar. Biol. Assoc. UK 84: 557-572. https://doi.org/10.1017/S0025315404009567h

Martí R., Uriz M.J., Ballesteros E., et al. 2004b. Temporal variation of several structure descriptors in animal-dominated benthic communities in two Mediterranean caves. J. Mar. Biol. Assoc. UK 84: 573-580. https://doi.org/10.1017/S0025315404009579h

Martin D., Ballesteros E., Gili J.M., et al. 1993. Small-scale structure of infaunal polychaete communities in an estuarine environment: Methodological approach. Estuar. Coast. Shelf. Sci. 36: $47-58$. https://doi.org/10.1006/ecss.1993.1004

McQuaid C.D. 1985. Seasonal variation in biomass and zonation of nine intertidal algae in relation to changes in radiation, sea temperature and tidal regime. Bot. Mar. 28: 539-544. https://doi.org/10.1515/botm.1985.28.12.539

Meese R.J., Tomich P.A. 1992. Dots on the rocks: A comparison of percent cover estimation methods. J. Exp. Mar. Biol. Ecol. 165: 59-73. https://doi.org/10.1016/0022-0981(92)90289-M

Niell F.X. 1979. Structure and succession in rocky algal communities of a temperate intertidal system. J. Exp. Mar. Biol. Ecol. 36: $185-200$ https://doi.org/10.1016/0022-0981(79)90108-4

Parravicini V., Micheli F., Montefalcone M., et al. 2010. Rapid assessment of epibenthic communities: A comparison between two visual sampling techniques. J. Exp. Mar. Biol. Ecol. 395: 21-29. https://doi.org/10.1016/j.jembe.2010.08.005

Piazzi L., Balata D., Cecchi E., et al. 2014. Effectiveness of different investigation procedures in detecting anthropogenic impacts on coralligenous assemblages. Sci. Mar. 78: 319-328. https://doi.org/10.3989/scimar.03989.28A

Romero J. 1981. Biomasa de comunidades de algas bentónicas de las islas Medes (Girona). Oecol. Aquat. 5: 87-93.

Russell D.J. 1990. Benthic algae: biomass and abundance. In: Phillips R.C., McRoy C.P. (eds), Seagrass Research Methods. UNESCO, Paris.

Sakai Y. 1977. Vegetation structure and standing crop of the marine algae in the Laminaria bed of Otaru city, Hokkaido, Japan. Jpn. J. Ecol. 27: 45-51.

Sala E., Ballesteros E. 1997. Partitioning of space and food resources by three fish of the genus Diplodus (Sparidae) in a Mediterranean rocky infralittoral ecosystem. Mar. Ecol. Progr. Ser. 152: 273-283.

https://doi.org/10.3354/meps 152273
Schonberg C.H.L. 2015. Monitoring bioeroding sponges: using rubble, quadrat, or intercept surveys? Biol. Bull. 228: 137-155. https://doi.org/10.1086/BBLv228n2p137

Sebens K.P. 1986. Spatial relationships among encrusting marine organisms in the New England subtidal zone. Ecol. Monogr. 56: 73-96. https://doi.org/10.2307/2937271

Shannon C.E. 1948. A mathematical theory of communication. Bell System Tech. J. 27: 379-423. https://doi.org/10.1002/j.1538-7305.1948.tb01338.x

Teixido N., Garrabou J., Arntz W.E. 2002. Spatial pattern quantification of Antarctic benthic communities using landscape indices. Mar. Ecol. Prog. Ser. 242: 1-14. https://doi.org/10.3354/meps242001

Teixido N., Garrabou J., Harmelin J.-G. 2011. Low dynamics, high longevity and persistence of sessile structural species dwelling on Mediterranean coralligenous outcrops. PLoS ONE 6: e23744. https://doi.org/10.1371/journal.pone.0023744

ter Braak C., Smilauer P. 1998. CANOCO reference manual and user's guide to Canoco for Windows: software for canonical community ordination (version 4). Microcomputer Power, Ithaca (NY), $352 \mathrm{pp}$.

Tomas F., Cebrian E., Ballesteros E. 2011. Differential herbivory of invasive algae by native fish in the Mediterranean Sea. Estuar. Coast. Shelf Sci. 92: 27-34. https://doi.org/10.1016/j.ecss.2010.12.004

True M.A. 1964. Dispositif pour récolte total du peuplement sur substrat dur. CIESMM, Coll. Comm. Benthos. pp. 25-27.

Trygonis V., Sini M. 2012. photoQuad: A dedicated seabed image processing software, and a comparative error analysis of four photoquadrat methods. J. Exp. Mar. Biol. Ecol. 424: 99-108. https://doi.org/10.1016/j.jembe.2012.04.018

Van Rein H., Schoeman D.S., Brown C.J., et al. 2011. Development of benthic monitoring methods using photoquadrats and scuba on heterogeneous hard-substrata: a boulder-slope community case study. Aquat. Conserv.: Mar. Freshw. Ecosyst. 21: 676-689. https://doi.org/10.1002/aqc.1224

Verlaque M. 1987. Contribution à l'étude du phytobenthos d'un ecosystème photophile termophile en Méditerranée Occidentale. Université d'Aix-Marseille, 389 pp.

Wethey D.S. 1984. Spatial pattern in barnacle settlement: day to day changes during the settlement season. J. Mar. Biol. Assoc. UK 64: 687-698. https://doi.org/10.1017/S0025315400030356

Whorff J.S., Griffing L. 1992. A video recording and analysis system used to sample intertidal communities. J. Exp. Mar. Biol. Ecol. 160: 1-12. https://doi.org/10.1016/0022-0981(92)90106-K

\section{SUPPLEMENTARY MATERIAL}

The following material is available through the online version of this article and at the following link:

http://scimar.icm.csic.es/scimar/supplm/sm04463esm.pdf

Table S1. - Species total biomass (g of dry weight) estimated with the collection method (2 replicates of $400 \mathrm{~cm}^{2}$ ). Depth is expressed in meters.

Table S2. - Species abundance (\%) estimated with the in situ visual method (4 replicates of $625 \mathrm{~cm}^{2}$ ). Depth is expressed in meters. See Table S3 for the "Complex 9" composition.

Table S3. - Species cover $\left(\mathrm{cm}^{2}\right)$ estimated with the photoquadrat method $\left(8\right.$ replicates of $\left.310 \mathrm{~cm}^{2}\right)$. Depth is expressed in meters.

Table S4. - Number of species $(\mathrm{N})$ and species diversity $\left(\mathrm{H}^{\prime}\right)$ for each depth, season and sampling method. $\mathrm{CV}$ is the seasonal coefficient of variation. 